\title{
HOME LEARNING PATTERN FOR INDONESIAN ELEMENTARY STUDENTS DURING COVID-19 PANDEMIC
}

\author{
Nurul Hidayah', Fitri Nur Mahmudah ${ }^{2}$ \\ Universitas Ahmad Dahlan, Indonesia ${ }^{1,2}$ \\ E-mail: nurul.pmat@gmail.com¹, fitri.mahmudah@mp.uad.ac.id ${ }^{2}$
}

DOI: 10.14421/al-bidayah.v13i1.610

\begin{abstract}
Changes in educational arrangements due to Covid-19 have led to new system adjustments for all elements, especially parents. This study aims to determine the learning patterns at home for elementary school students during the Covid-19 pandemic. This study employed qualitative research methods. The approach used was a case study that was performed in the researcher's home environment. Participants consisted of six people and six schools. The data collection technique used a focus group discussion (FGD) with discussion guidelines. The research procedure employed the Creswell model. Data analysis was conducted with the Atlas.ti software version 8. This study observed learning patterns at home during the Covid-19 pandemic, which was by having indicators comprising of convenience place, parental assistance, activity, effective learning, and anticipate problems.
\end{abstract}

\section{Keywords: elementary school students; home learning patterns; the COVID-19 pandemic}

\section{INTRODUCTION}

The Covid-19 pandemic has become a phenomenon that all people have suffered from various sectors of life, such as health, economy, education and other sectors. For months forged by the Covid-19 pandemic, the government immediately performed steps deemed effective to overcome the spread of this virus. In the education sector, through the ministry of education and culture, the government has adopted a new policy to break the chain of Covid-19 spread, which was through the "Learning from Home" program. It is stated in a circular ${ }^{1}$ that "learning from home aims to ensure the fulfillment of students' rights to get educational services during the Covid-19 emergency".

The purpose of learning is to fulfill the obligations and rights of education. Distance learning is the main thing in delivering material amid the conditions of the Covid-19 pandemic ${ }^{2}$.

${ }^{1}$ Secretary General of the Ministry of Education and Culture, "Circular Letter of the Secretary General of the Ministry of Education and Culture Number 15/2020 Concerning Guidelines for Organizing Learning from Home in an Emergency Period for the Spread of Corona Virus Disease (COCID-19)" (Jakarta, Indonesia: Ministry of Education and Culture (MOEC), 2020), 1-20.a

${ }^{2}$ Suryo Raden Adji Utomo and Fitri Nur Mahmudah, "The Implementation of Distance Learning during the Covid-19 Pandemic," Jurnal Madrasah 13, no. 2 (2021): 114-25, https://doi.org/10.18860/mad.v13i2.11330. 
It requires a different innovation in learning ${ }^{3}$. Learning adjustments also require joint contributions ${ }^{4}$. This condition causes all teachers and students to learn remotely. Data from the Ministry of Education and Culture provide an overview of the number of those who undertake distance learning.

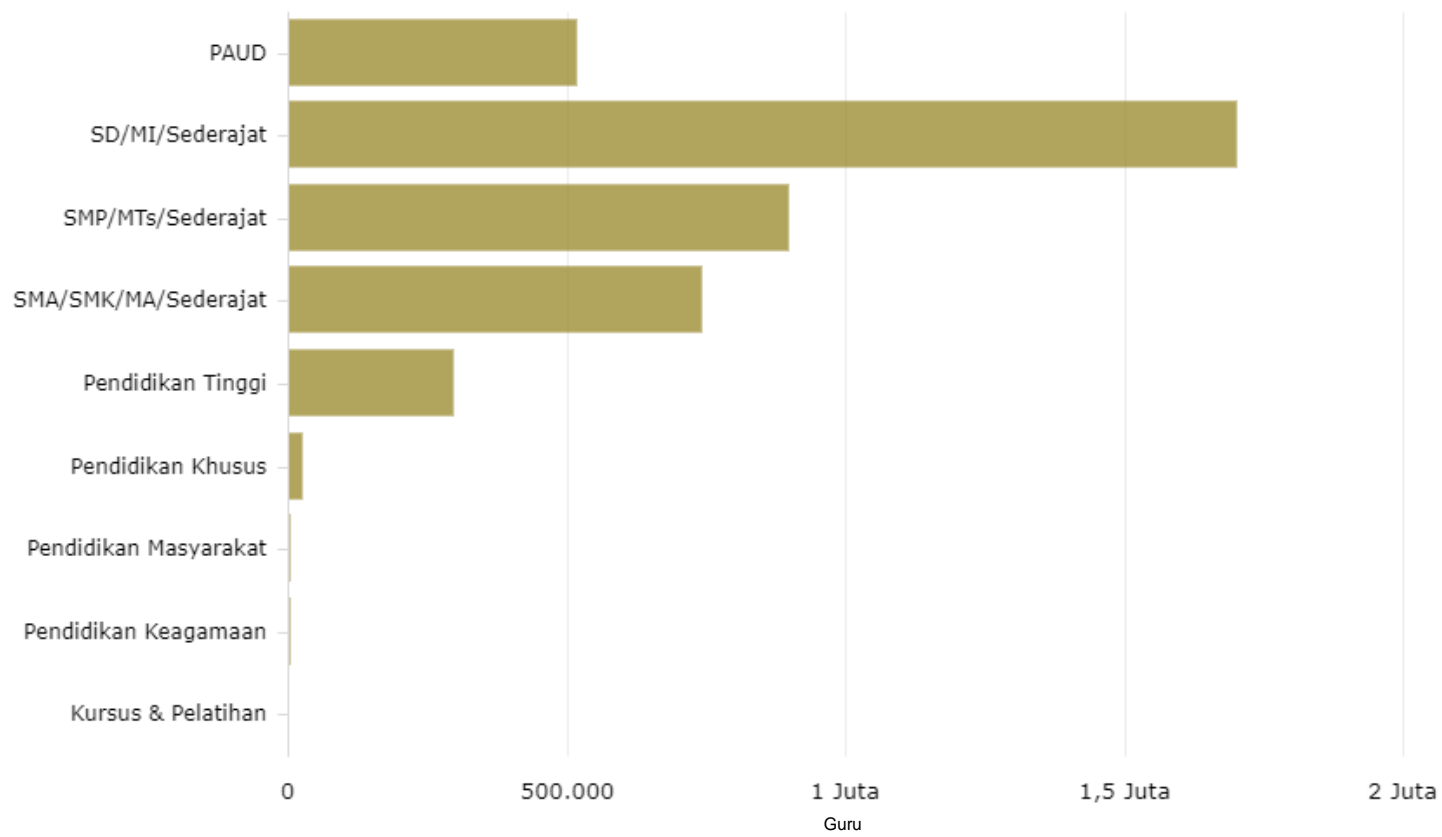

Figure 1

Number of Teachers and Lecturers Teaching Remotely

Source: Ministry of Education and Culture, 2020

Figure 1 above can be interpreted that the amount of learning performed remotely is at the elementary school level (or called SD/MI/Sederajat in figure 1). There are 68.729.037 students $^{5}$. It means that elementary school students have the highest number in the learning process. The data can be used as a reference in the complexity of opportunities, obstacles, and success in the learning process at home. Various efforts need to be performed to keep learning at home. Elementary school students are one of the subjects affected by the Covid-19 pandemic. Therefore, it requires extra attention

${ }^{3}$ Fitri Nur Mahmudah, "Self-Innovation Guru Dalam Meningkatkan Prestasi Siswa Pada Masa Pandemi COVID-19," Ta'dibuna: Jurnal Pendidikan Islam 10, no. 1 (2021): 119-34, https://doi.org/10.32832/tadibuna.v10i1.4075.

${ }^{4}$ Director General of Teachers and Education Personnel, "Distance Learning Guide For Teachers During School Closes And Covid-19 Pandemic With The Spirit Of Freedom To Learn" (Jakarta, Indonesia: Ministry of Education and Culture (MOEC), 2020).

${ }^{5}$ Minister of Education and Culture, 'Parents' Guide in Assisting Children's Learning During the Covid-19 Pandemic" (Jakarta, Indonesia: Ministry of Education and Culture (MOEC), 2020). 
from various parties, especially parents. Because elementary school students need parental help in learning, learning at home is ideally accompanied by parents.

Parental assistance is a primary need for elementary school students studying at home. It is completed because the importance of parental assistance conveys assumptions $^{6}$ due to children's behaviour that often changes (moody). Likewise, it is related to the "low learning motivation of students"7. Parental assistance in the child's learning process is an attempt by parents to accompany ${ }^{8}$, provide assistance in overcoming children's learning problems ${ }^{9}$, provide encouragement, motivation, support, supervise, and provide facilities for children to learn ${ }^{10}$. The same thing was also conveyed by ${ }^{11}$ that "there is a need for assistance in learning at home during Covid-19 that parents can provide, including helping when children have difficulties, guiding and even providing a deeper exploration of learning related to the provided assignment".

The problems which arise when studying at home by students are a part which must be considered and studied. "Children's learning assistance is seen from the way parents assist children's task difficulties, explain the material that children do not understand, and respond well to all online learning from school"12. Therefore, it is significant to understand patterns that can reference parents in learning assistance at students' homes during Covid-19. It is given that the parents of each student have different backgrounds and conditions. Heterogeneous parental conditions led to differences in learning patterns performed during the home learning program.

${ }^{6}$ Direktorat Jenderal Pendidikan Islam, "Panduan Orang Tua Dalam Pendampingan Belajar Anak Pada Masa Pandemi Covid-19” (Jakarta, Kementerian Agama Republik Indonesia, 2020).

7 Kurnia Dwi Setyaningsih, "Analisis Pelaksanaan Pembelajaran Jarak Jauh Di SD Negeri Karangrena 03," Jurnal Riset Pendidikan Dasar (JRPD) 1, no. 2 (September 11, 2020), https://doi.org/10.30595/.v1i2.9012.

${ }^{8}$ Cecilia Sin-sze Cheung and Eva M Pomerantz, "Parents ' Involvement in Children's Learning in the United States and China: Implications for Children 's Academic and Emotional Adjustment," Child Development 82, no. 3 (2011): 932-50, https://doi.org/10.1111/j.1467-8624.2011.01582.x.

${ }^{9}$ Đurišić, Maša, and Mila Bunijevac. "Parental Involvement as a Important Factor for Successful Education." Center for Educational Policy Studies Journal 7, no. 3 (September 25, 2017): 137-53. https://www.cepsj.si/index.php/cepsj/article/view/291.

${ }^{10}$ Fajar Ahmad Dwi Prasetyo, "Pendampingan Orang Tua Dalam Proses Belajar Anak: Studi Deskriptif Tentang Tingkat Optimalisasi Pendampingan Orang Tua Dalam Proses Belajar Anak Menurut Persepsi Siswa Kelas X SMK N 1 Nanggulan Tahun Ajaran 2017/2018” (Universitas Sanata Dharma, 2018).

${ }^{11}$ Betty Kusumaningrum et al., "Pendampingan Orangtua Dalam Pembelajaran Daring Di Sekolah Dasar: :," INVENTA: Jurnal Pendidikan Guru Sekolah Dasar 4, no. 2 (September 30, 2020): 142-50, https://doi.org/10.36456/inventa.4.2.a2607.

12 Wiwin Yulianingsih and Rivo Nugroho, "Keterlibatan Orangtua Dalam Pendampingan Belajar Anak Selama Masa Pandemi Covid-19," Jurnal Obsesi: Jurnal Pendidikan Anak Usia Dini 5, no. 2 (2021): 1138-50, https://doi.org/10.31004/obsesi.v5i2.740. 
Therefore, this study aims to discover the exact patterns that can be used in home learning during the Covid-19 pandemic.

\section{RESEARCH METHODS}

This study used qualitative research methods. The approach employed a case study. Using the case study method was to gather information about learning patterns at home for elementary school students. The reasons as asserted by ${ }^{13}$ that "case study research involves the study of an issue explored through one or more cases within a bounded system." This research setting was conducted around the researcher's house, where the researcher observed the existing symptoms associated with studying at home by elementary school students.

The participants in this study were parents and teachers. This technique of selecting participants used purposive. Purposive sampling is a technique for sampling data sources with certain considerations ${ }^{14}$. Participants in this study are seen in table 1

Table 1

Research Participants

\begin{tabular}{clc}
\hline No. & \multicolumn{1}{c}{ Source of Participants } & $\begin{array}{c}\text { Number of } \\
\text { Participants }\end{array}$ \\
\hline 1 & Muhammaadiyah Karangkajen 4 Primary School & 1 \\
2 & Muhammadiyah Nitikan Primary School & 1 \\
3 & Muhammadiyah Pandeyan Primary School & 1 \\
4 & Prambanan MBS Primary School & 1 \\
5 & Muhammadiyah Mertoyudan Primary School & 1 \\
6 & Demangan Public ELementary School & 1 \\
7 & Parents & 6 \\
\hline
\end{tabular}

The participants' determination in this study is based on activities in providing assignments and teaching for students at home. The heterogeneity of these participant characteristics was raised to obtain complete data.

The technique used in this research is Focus Group Discussion (FGD). This FGD technique was employed to discover comprehensive answers to research participants in the learning practices provided by students while studying at home

${ }^{13}$ John W. Creswell, Second Edition Qualitative Inquiry \& Research Design. Choosing Among Five Apporaches (SAGE Publications Asia-Pacific Pte. Ltd., 2007).

14 Saumya Verma et al., "Sampling Typology and Techniques," International Journal for Scientific Research and Development 5, no. 9 (December 1, 2017): 298-301, http://ijsrd.com/ http://www.ijsrd.com/. 
during the Covid-19 pandemic. Researchers may find many meanings from the practices conducted by teachers in various elementary schools, which are the object of this research study. It is consistent with the statement that "focus group discussion is frequently used as a qualitative approach to gain an in-depth understanding of social issues." 15 The same thing was conveyed in that article "Focus group is a type of indepth interview accomplished in a group, which meetings present characteristics defined concerning the proposal, size, composition, and interview procedures"16. FGD was conducted in research using the zoom cloud meeting.

This research procedure used a model Denzin $\& \operatorname{Lincoln}{ }^{17}$. There were five steps employed to be able to complete this research, which are:

1. Creating a conceptualization of the research object by compiling a research framework related to learning patterns. The learning of elementary school students is very complex; hence, the first reference in this research study is related to students studying at home during the Covid-19 pandemic. This distance learning performed at home requires an ideal pattern to be applied to all elementary school students. It is needed to anticipate boredom in the monotonous learning provided by the teacher.

2. Then, it is determining the selected themes through the symptoms seen in remote learning practices by teachers and students at home. The most important theme is in order to improve the students' achievement. Therefore, it required an ideal pattern to be able to reveal existing problems.

3. Taking data and tracing data patterns to enrich data related to learning at home during the Covid-19 pandemic. The data collected were then analyzed employing the help of the Atlas.ti software version 8. This analysis was performed to reduce many data by getting data according to the theme and study ${ }^{18}$, which is the learning patterns of elementary school students at home during the Covid-19 pandemic.

\footnotetext{
15 Tobias O Nyumba et al., "The Use of Focus Group Discussion Methodology: Insights from Two Decades of Application in Conservation," Methods in Ecology and Evolution 2018, no. March 2017 (2018): 20-32, https://doi.org/10.1111/2041-210X.12860.

${ }^{16}$ Lokanath Mishra, "Focus Group Discussion in Qualitative Research," TechnoLEARN 6, no. 1 (2016): 1-5, https://doi.org/10.5958/2249-5223.2016.00001.2.

${ }^{17}$ Norman K. Denzin and Yvonna S. Lincoln, The Sage Handbook of Qualitative Research Fifth Edition (United States: SAGE Publications, Inc., 2018).

${ }^{18}$ Fitri Nur Mahmudah, Analisis Data Penelitian Kualitatif Manajemen Pendidikan Berbantuan Software Atlas.Ti Versi 8 (Yogyakarta: UAD Press, 2021).
} 
Furthermore, the analysis was conducted to obtain a concept map from the results of this study.

4. After being analyzed, the next step was validating the process using triangulation techniques. The researcher returned to the FGD to confirm the data analyzed, and the results were obtained to the participants. It is completed to improve the quality of qualitative research data and serve as a basis for making conclusions or interpretations.

5. The final step is to write down the conclusions of this qualitative study.

\section{RESULT AND DISCUSSION}

The increasingly massive spread of Covid-19 requires the government to conduct effective preventive measures immediately. In the field of education, the home learning policy is the best solution in implementing education. The home learning program can be implemented using two methods which are online distance learning and offline distance learning. The home study program was responded to positively by parents of students, especially elementary school students. It is because elementary school students who are still children are very vulnerable to contracting and potentially transmitting the virus. As long as the Covid-19 pandemic occurs, schools are provided the freedom to regulate the learning curriculum. Schools can apply different learning curricula with each other.

During the Covid-19 Pandemic, the home study program was greatly influenced by the participation of parents in learning assistance. Parents of students process different activities from one another so that studying at home for each student also experiences differences. Some parents work, and some parents do not work, so that the available time of students to study is also different. The classification of learning patterns at homes of elementary school students during the Covid-19 pandemic is presented in table 2 . 
Table 2

Classification of Learning Patterns at Students' Homes During the Covid-19 Pandemic

\begin{tabular}{ccccccc}
\hline \multicolumn{2}{c}{ Parent } & \multicolumn{2}{c}{ Teacher } & \multicolumn{3}{c}{ Time to Learn } \\
\hline Work & Not Work & $\checkmark$ & X & Morning & Evening & Night \\
\hline$\square$ & & & & $\square$ & $\square$ & $\square$ \\
\hline$\square$ & & $\square$ & & $\square$ & $\square$ \\
\hline & $\square$ & & $\square$ & & $\square$ \\
\hline & $\square$ & $\square$ & & Flexible &
\end{tabular}

From table 2 above, it can be identified that parents who work and have tutors, the time for student tutoring is more, while parents who work without tutors own less time for tutoring. Meanwhile, for parents who do not work and have no tutors, the study schedule is uncertain or flexible according to students' mood. Furthermore, based on the research data that has been carried out, the following are the results of qualitative research data analysis with the assistance of Atlas.ti software version 8.3

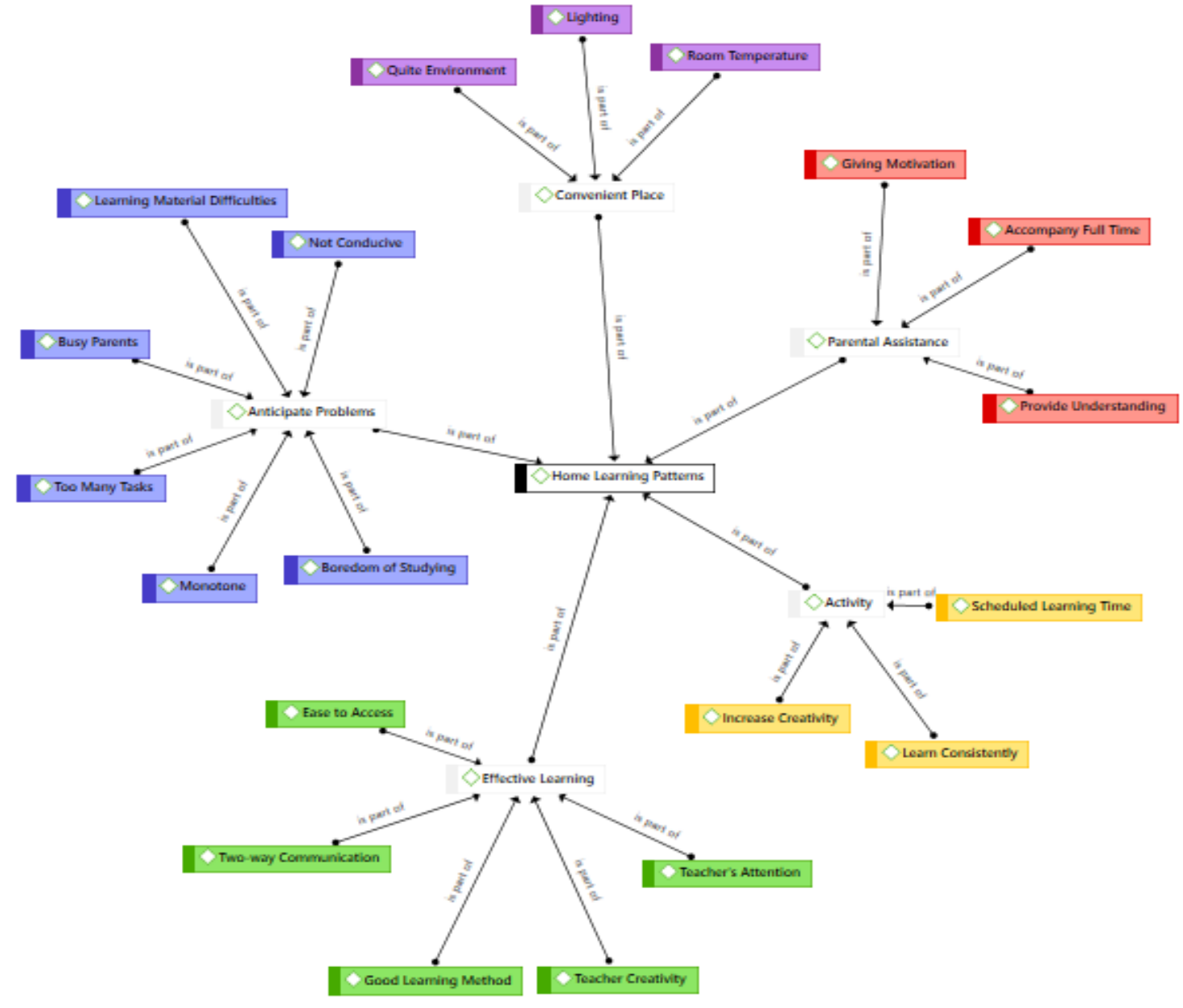

Figure 2

Results of Qualitative Research Data Analysis Assisted by Atlas.ti Software 8.3 
Based on the results of data analysis in Figure 2, it can be interpreted that the patterns which are necessary to be used by teachers and parents when providing learning to elementary school students at home are based on the convenience place, parental assistance, activity, effective learning, and anticipate problems. The findings from the data analysis of this study provide the latest information related to learning patterns at home. The results of this study are in line with the statement discussing the parents as a vital role in handling the home education environment for children. However, not all parents meet the standard criteria to deal with learning at home ${ }^{19}$. The results of this study become the latest study for a learning model at home during the Covid-19 pandemic. It is because there are research results which state that seeing home-school as a deficit model ${ }^{20}$. In distance learning, the role of parents is also involved in the learning process. Parents must accompany, direct and even become educators for students during teaching and learning activities at home ${ }^{21}$.

Therefore, the findings indicators answer the formulation of this research problem. The pattern is needed by all students and parents when studying at home and is needed by the teacher to conduct evaluations so that learning continues and does not cause boredom for students studying at home. Indicators of the findings of this study will be discussed in the following section:

\section{Convenient Place}

A comfortable place to study is the carrying capacity for elementary school students to study and follow the learning provided by teachers at school. A comfortable place is the first factor for students to study well. A calm place can make the heart condition calm too. Hence, students can have the good concentration to focus on learning. The findings of this study on a convenient place have several indicators, which are a quiet environment, lighting, and room temperature. These three things can

${ }^{19}$ Chusna Apriyanti, "The Parents Role in Guiding Distance Learning and the Obstacle during Covid-19 Outbreak," Jurnal Ilmiah Pendidikan Dasar VII, no. 2 (2020): 68-83, https://doi.org/10.30659/pendas.7.2.68-83.

${ }^{20}$ Sara Bubb, "Improving Schools Learning from the COVID-19 Home-Schooling Experience: Listening to Pupils , Parents / Carers and Teachers," Improving Schools 23, no. 3 (2020): 209-22, https://doi.org/10.1177/1365480220958797.

${ }^{21}$ Veronika Veronika, Wawan Setiawan, and Nurul Fazriyah, "Students' Learning Motivation in Distance Learning During the COVID- 19 Pandemic Period at Primary School," International Conference on Elementary Education 3, no. 1 (April 12, 2021): 359-63, http://proceedings2.upi.edu/index.php/icee/article/view/1486. 
determine a comfortable place to study. The study results follow the following statement, that place-based learning through this program engages futures teachers with experiences in the communities, and the hopeful result is to increase the cultural understanding and the ability to lead within these communities ${ }^{22}$. Place-based learning approaches seek to capitalize on the strong affinity people have for their communities to accomplish ecological and cultural literacy and a range of conservation and community stewardship objectives ${ }^{23}$. Therefore, it is essential to have a comfortable place to concentrate on primary school students while studying at home during the Covid-19 pandemic. It also increases self-sensitivity to the material provided by the teacher and is ultimately able to improve the learning outcomes and learn achievement of the students.

\section{Parental Assistance}

Learning for primary school students at home during the Covid-19 pandemic certainly needs the help of parents. It can be performed together because elementary school students are still not good at using technology or media in learning, likewise, in terms of access to material provided by the teacher. However, the importance of the role of parents in children's learning at home will increase bonding between parent and child. The finding of the results of this study is that parental assistance owns several useful indicators, which are giving motivation, accompanying full time, and providing understanding. There are many benefits encountered by students when parents can assist children's learning at home. Learning assistance is meant starting from the presence of parents when their children perform homework from teachers at school to the provision of learning facilities for their children in home study ${ }^{24}$. Parental assistance (or involvement) refers to a situation where parents are directly involved in their children's education. They involve themselves and are involved by the school and teachers in their children's learning process, and they fulfil their duties as parents in making sure that the learner is assisted in the process of learning as much as they

22 Jeanne Surface, "Place-Based Learning: Instilling A Sense Of Wonder," Publications of the Rural Futures Institute, July 27, 2016, https://digitalcommons.unl.edu/rfipubs/10.

${ }_{23}$ Cheryl Charles and Richard Louv, "Children's Nature Deficit: What We Know and Don't Know," Children and Nature Network, http://strawberry.audubon.org/sites/default/files/cnnevidenceofthedeficit.pdf.

${ }^{24}$ Andy Sapta, Abdul Hamid, and Edi Syahputra, "Assistance of Parents in the Learning at Home," Journal of Physics: Conference Series 1, no. 1114 (2018): 1-6, https://doi.org/10.1088/1742$6596 / 1114 / 1 / 012020$. 
possibly $\operatorname{can}^{25}$. The importance of parental involvement needs to be considered. Thus, one of the things children can conduct to follow the learning well is through help and attention from parents.

\section{Activity}

The main activity in children's learning at home during the Covid-19 pandemic is that children can follow the learning well. The presence of children in the course of learning or in the active collection of assignments on time is the last thing for learning implementation. The teacher finds it easier to monitor the attendance and assignments collected by the students. This study found important indicators that need to be considered together that children's activities while learning at home require consistent learning, schedule learning time, and increasing creativity. There are several schools where the implementation of learning does not use zoom cloud meetings during class hours. Some use asynchronous systems. It means that the teacher requires the presence of students as an activity to participate in learning. The students were also discovered to have a significant deficit in their engagement in home-learning tasks as informed by the four lifelong learning skills on which the study focused ${ }^{26}$. It can improve children's creativity and skills. Activities at home such as reading the book, telling stories and singing songs for reading performance in later primary school in children's first and second language ${ }^{27}$ can be the alternative activities students may implement. Hence, increasing children's learning activities at home requires a learning schedule. This aim can learn consistently and increase children's creativity.

\section{Effective Learning}

The achievement of learning is due to effective learning. It can be interpreted as learning which succeeds in achieving student learning goals as expected by the teacher. Even though the implementation of remote learning and during the Covid-19 pandemic. The findings of this study provide important indicators for effective learning, which are

25 Abie Ntekane, "Parental Involvement in Education," Research Gate 1, no. April (2018): 1-5, https://doi.org/10.13140/RG.2.2.36330.21440.

${ }^{26}$ Tanju Deveci, "Homework vs. Home-Learning: A Lifelong Learning Perspective and Student Perceptions," ESBB 5, no. 1 (June 23, 2019): 57-80,http://www.englishscholarsbeyondborders.org/wpcontent/uploads/2019/06/Tanju-Deveci.pdf.

27 Shek Kam Tse, "The Effects of Home Reading Activities during Preschool and Grade 4 on Children' s Reading Performance in Chinese and English in Hong Kong," ACER: Australian Council for Educational Research 61, no. 1 (2017): 5-23, https://doi.org/10.1177/0004944116689093. 
teacher's attention, teacher creativity, good learning method, ease of access, and twoway communication. One of the symptoms and effects of ineffective learning is when the teacher and parents do not match, both in terms of communication that is not twoway, parents' material presented cannot be understood by parents and the difficulties in accessing material for use in learning. Therefore, learning management is needed to be more effective. Home learning and management during Covid-19 to obtain an insight into real-life experiences ${ }^{28}$. Teachers can use virtual classrooms to teach from home with all necessary tools, making the online sessions as effective as the conventional or offline classes $^{29}$. The learning program's effectiveness is not only in terms of the level of learning achievement but must also be reviewed in terms of the processes and supporting facilities ${ }^{30}$. It means that effective learning makes use of all resources to optimize distance learning.

\section{Anticipating Problem}

All learning activities both face-to-face at school and remotely at home may create problems. The right solution is to be able to anticipate any possibility used to support successful learning. The findings from this study indicate that the steps in anticipating problems encountered by students learning at home are not conducive, learning material difficulties, busy parents, too many tasks, monotone, and boredom of studying. A problem is much bigger in families who also report difficulties in balancing the demands of work and family, especially those with children in elementary school ${ }^{31}$. The challenges encountered by teachers when frequently occur when teaching learners with developmental and how to try to overcome these challenges ${ }^{32}$. Learners with

28 Shelina Bhamani, "Home Learning in Times of Covid: Experiences of Parents," Journal of Education and Educational Development 7, no. 1 (2020): 9-26, https://doi.org/10.22555/joeed.v7i1.3260.

${ }^{29}$ Pravat Kumar Jena, “Online Learning during Lockdown Period for COVID-19 in India," SSRN Scholarly Paper (Rochester, NY: Social Science Research Network, May 31, 2020), https://papers.ssrn.com/abstract=3691545.

30 Bernadetha Nadeak, "The Effectiveness of Distance Learning Using Social Media during the Pandemic Period of COVID-19: A Case in Universitas Kristen Indonesia," International Journal of Advanced Science and Technology 29, no. 7 (2020): 1764-72, http://sersc.org/journals/index.php/ijast.

31 Robert Sweet, Anisef Paul, and Maria Adamuti-Trache, Managing The Home Learning Environment: Parents, Adolescents, And The Homework Problem (Ottawa, Canada: The Canadian Council On Learning, 2007), https://www.researchgate.net/publication/242478415_MANAGING_THE_HOME_LEARNING_ENVIR ONMENT_PARENTS_ADOLESCENTS_AND_THE_HOMEWORK_PROBLEM.

${ }^{32}$ Humphrey Alexander Udoba, "Challenges Faced By Teachers When Teaching Learners With Developmental Disability” (Master Thesis, Norwegia, University of Oslo, 2014), http://urn.nb.no/URN:NBN:no-46844. 
emotional problems experience behaviour problems which serve as barriers to effective learning ${ }^{33}$. Children's home learning experiences vary over time, and they also present how different groups of children can be identified based on such a longitudinal perspective ${ }^{34}$. Therefore, it is important to identify problems that may arise and occur. Hence, children may learn in pleasant conditions ${ }^{35}$. It aims to conduct concrete steps to anticipate and provide the best solutions related to problems existing during the implementation of distance learning.

\section{CONCLUSION}

Based on the results of research and discussion, it can be concluded that the distance learning process during the Covid-19 pandemic performed at home is a concept which needs to be conducted to continue implementing education. Elementary school students are students whose independence is still under the supervision of their parents. Therefore, learning at home during the Covid-19 pandemic requires full parental involvement. The results of this study provide the best pattern of home learning. Some things which need to be considered are how the parents are involved. Time management and learning management, anticipating problems, and communication also need to be considered between teachers and parents so that the material provided can be accepted and performed by children while studying at home. The limitation of this study is that there is no observation in the learning process due to the Covid-19 pandemic. Thus, the data collected is still not rich and deep.

The results of this study may become recommendations for parents and teachers. It is necessary to consider the concept of learning at home, which is easily accessible, teacher creativity in providing learning material, and parental involvement. Learning for primary school students at home during the Covid-19 pandemic will run as expected if the teacher can understand material and material and good communication to parents.

${ }^{33}$ Franscina Hester Weeks, "Behaviour Problems In The Classroom : A Model For Teachers To Assist Learners With Unmet Emotional Needs" (Thesis, Gauteng, South Africa, University of South Africa, 2000), https://uir.unisa.ac.za/handle/10500/17854.

${ }^{34}$ Simone Lehrl, Maria Evangelou, and Pam Sammons, "The Home Learning Environment and Its Role in Shaping Children' s Educational Development," School Effectiveness and School Improvement. An International Journal of Research, Policy and Practice 31, no. 1 (2020): 1-6, https://doi.org/10.1080/09243453.2020.1693487.

35 KN Widyaningrum and Fitri Nur Mahmudah, "Kreasi Iklim Sekolah Melalui Gerakan Menyenangkan Di SD Muhammadiyah Mantara," Jurnal Kependidikan 6, no. 2 (2019): 115-28, https://doi.org/10.23917/ppd.v1i2.9259. 
Furthermore, parents can spend time accompanying children's learning at home. Hence, children can learn comfortably, calmly, happily and be able to improve learning achievement. This pattern can be performed by anyone, including suggestions for all parents who like to assist their children in learning at home. This research is also recommended for further research related to the development of learning models at home.

\section{ACKNOWLEDGMENTS}

The researcher would like to thank the school principals, teachers, and parents who have assisted in this research process, from six elementary schools in the Province of the Special Region of Yogyakarta, namely: Muhammadiyah Karangkajen 4 Primary School, Muhammadiyah Nitikan Primary School, Muhammadiyah Pandeyan Primary School, Prambanan MBS Primary School, Muhammadiyah Mertoyudan Primary School, and Demangan State Primary School.

\section{DECLARATION OF CONFLICTING INTERESTS}

The author/s declared no potential conflicts of interest with respect to the research, authorship, and/or publication of this article.

\section{FUNDING}

There is no institution funding this research. This research was conducted independently by the authors.

\section{ORCID iD}

Nurul Hidayah $\quad$ (iD) https://orcid.org/0000-0002-6047-1547

Fitri Nur Mahmudah (iD https://orcid.org/0000-0002-2757-3605

\section{REFERENCES}

Apriyanti, Chusna. "The Parents Role in Guiding Distance Learning and the Obstacle during Covid-19 Outbreak." Jurnal Ilmiah Pendidikan Dasar VII, no. 2 (2020): 68-83. https://doi.org/10.30659/pendas.7.2.68-83.

Bhamani, Shelina. "Home Learning in Times of Covid: Experiences of Parents." Journal of Education and Educational Development 7, no. 1 (2020): 9-26. https://doi.org/10.22555/joeed.v7i1.3260. 
Bubb, Sara. "Improving Schools Learning from the COVID-19 Home-Schooling Experience : Listening to Pupils , Parents / Carers and Teachers." Improving Schools 23, no. 3 (2020): 209-22. https://doi.org/10.1177/1365480220958797.

Charles, Cheryl, and Richard Louv. "Children's Nature Deficit: What We Know and Don't Know." Children and Nature Network, 2009, 1-32. http://strawberry.audubon.org/sites/default/files/cnnevidenceofthedeficit.pdf.

Cheung, Cecilia Sin-sze, and Eva M Pomerantz. 'Parents' Involvement in Children's Learning in the United States and China: Implications for Children' s Academic and Emotional Adjustment." Child Development 82, no. 3 (2011): 932-50. https://doi.org/10.1111/j.1467-8624.2011.01582.x.

Creswell, John W. Second Edition Qualitative Inquiry \& Research Design. Choosing Among Five Apporaches. SAGE Publications Asia-Pacific Pte. Ltd., 2007.

Denzin, Norman K., and Yvonna S. Lincoln. The Sage Handbook of Qualitative Research Fifth Edition. United States: SAGE Publications, Inc., 2018.

Deveci, Tanju. "Homework vs. Home-Learning: A Lifelong Learning Perspective and Student Perceptions." ESBB 5, no. 1 (June 23, 2019): 5780.http://www.englishscholarsbeyondborders.org/wpcontent/uploads/2019/06/Tanju-Deveci.pdf.

Director General of Teachers and Education Personnel. "Distance Learning Guide For Teachers During School Closes And Covid-19 Pandemic With The Spirit Of Freedom To Learn." Jakarta, Indonesia: Ministry of Education and Culture (MOEC), 2020.

Direktorat Jenderal Pendidikan Islam. "Panduan Orang Tua Dalam Pendampingan Belajar Anak Pada Masa Pandemi Covid-19.” Jakarta, Kementerian Agama Republik Indonesia, 2020.

Đurišić, Maša, and Mila Bunijevac. "Parental Involvement as a Important Factor for Successful Education.” Center for Educational Policy Studies Journal 7, no. 3 (September 25, 2017): 137-53. https://www.cepsj.si/index.php/cepsj/article/view/291.

Jena, Pravat Kumar. "Online Learning during Lockdown Period for COVID-19 in India." SSRN Scholarly Paper. Rochester, NY: Social Science Research Network, May 31, 2020. https://papers.ssrn.com/abstract=3691545.

KN Widyaningrum, and Fitri Nur Mahmudah. "Kreasi Iklim Sekolah Melalui Gerakan Menyenangkan Di SD Muhammadiyah Mantara." Jurnal Kependidikan 6, no. 2 (2019): 115-28. https://doi.org/10.23917/ppd.v1i2.9259.

Kusumaningrum, Betty, Krida Singgih Kuncoro, Tri Astuti Arigiyati, and Trisniawati. "Pendampingan Orangtua Dalam Pembelajaran Daring Di Sekolah Dasar: :" INVENTA: Jurnal Pendidikan Guru Sekolah Dasar 4, no. 2 (September 30, 2020): 142-50. https://doi.org/10.36456/inventa.4.2.a2607.

Lehrl, Simone, Maria Evangelou, and Pam Sammons. "The Home Learning Environment and Its Role in Shaping Children's Educational Development." School Effectiveness and School Improvement. An International Journal of 
Research, Policy and Practice 31, no. 1 (2020): 1-6. https://doi.org/10.1080/09243453.2020.1693487.

Mahmudah, Fitri Nur. Analisis Data Penelitian Kualitatif Manajemen Pendidikan Berbantuan Software Atlas.Ti Versi 8. Yogyakarta: UAD Press, 2021.

Mahmudah, Fitri Nur. "Self-Innovation Guru Dalam Meningkatkan Prestasi Siswa Pada Masa Pandemi COVID-19." Ta'dibuna: Jurnal Pendidikan Islam 10, no. 1 (2021): 119-34. https://doi.org/10.32832/tadibuna.v10i1.4075.

Minister of Education and Culture. "Parents' Guide in Assisting Children's Learning During the Covid-19 Pandemic." Ministry of Education and Culture (MOEC), 2020.

Mishra, Lokanath. "Focus Group Discussion in Qualitative Research." TechnoLEARN 6, no. 1 (2016): 1-5. https://doi.org/10.5958/2249-5223.2016.00001.2.

Nadeak, Bernadetha. "The Effectiveness of Distance Learning Using Social Media during the Pandemic Period of COVID-19: A Case in Universitas Kristen Indonesia." International Journal of Advanced Science and Technology 29, no. 7 (2020): 1764-72. http://sersc.org/journals/index.php/ijast.

Ntekane, Abie. "Parental Involvement in Education." Research Gate 1, no. April (2018): 1-5. https://doi.org/10.13140/RG.2.2.36330.21440.

Nyumba, Tobias O, Kerrie Wilson, Christina J Derrick, and Nibedita Mukherjee. "The Use of Focus Group Discussion Methodology: Insights from Two Decades of Application in Conservation." Methods in Ecology and Evolution 2018, no. March 2017 (2018): 20-32. https://doi.org/10.1111/2041-210X.12860.

Prasetyo, Fajar Ahmad Dwi. "Pendampingan Orang Tua Dalam Proses Belajar Anak: Studi Deskriptif Tentang Tingkat Optimalisasi Pendampingan Orang Tua Dalam Proses Belajar Anak Menurut Persepsi Siswa Kelas X SMK N 1 Nanggulan Tahun Ajaran 2017/2018." Universitas Sanata Dharma, 2018.

Sapta, Andy, Abdul Hamid, and Edi Syahputra. "Assistance of Parents in the Learning at Home." Journal of Physics: Conference Series 1, no. 1114 (2018): 1-6. https://doi.org/10.1088/1742-6596/1114/1/012020.

Secretary General of the Ministry of Education and Culture. "Circular Letter of the Secretary General of the Ministry of Education and Culture Number 15/2020 Concerning Guidelines for Organizing Learning from Home in an Emergency Period for the Spread of Corona Virus Disease (COCID-19)." Jakarta, Indonesia: Ministry of Education and Culture (MOEC), 2020

Setyaningsih, Kurnia Dwi. "Analisis Pelaksanaan Pembelajaran Jarak Jauh Di SD Negeri Karangrena 03." Jurnal Riset Pendidikan Dasar (JRPD) 1, no. 2 (September 11, 2020). https://doi.org/10.30595/.v1i2.9012.

Surface, Jeanne. "Place-Based Learning: Instilling A Sense Of Wonder." Publications of the Rural Futures Institute, July 27, 2016. https://digitalcommons.unl.edu/rfipubs/10.

Sweet, Robert, Anisef Paul, and Maria Adamuti-Trache. Managing The Home Learning Environment: Parents, Adolescents, And The Homework Problem. Ottawa, Canada: The Canadian Council On Learning, 2007. 
https://www.researchgate.net/publication/242478415_MANAGING_THE_HO ME_LEARNING_ENVIRONMENT_PARENTS_ADOLESCENTS_AND_TH E_HOMEWORK_PROBLEM.

Tse, Shek Kam. "The Effects of Home Reading Activities during Preschool and Grade 4 on Children' s Reading Performance in Chinese and English in Hong Kong." ACER: Australian Council for Educational Research 61, no. 1 (2017): 5-23. https://doi.org/10.1177/0004944116689093.

Udoba, Humphrey Alexander. "Challenges Faced By Teachers When Teaching Learners With Developmental Disability.” Master Thesis, University of Oslo, 2014. http://urn.nb.no/URN:NBN:no-46844.

Utomo, Suryo Raden Adji, and Fitri Nur Mahmudah. "The Implementation of Distance Learning during the Covid-19 Pandemic.” Jurnal Madrasah 13, no. 2 (2021): 114-25. https://doi.org/10.18860/mad.v13i2.11330.

Verma, Saumya, RAjneesh Kumar Gautam, Spriha Pandey, Aman Mishra, and Shubham Shukla. "Sampling Typology and Techniques." International Journal for Scientific Research and Development 5, no. 9 (December 1, 2017): 298-301. http://ijsrd.com/ http://www.ijsrd.com/.

Veronika, Veronika, Wawan Setiawan, and Nurul Fazriyah. "Students' Learning Motivation in Distance Learning During the COVID- 19 Pandemic Period at Primary School." International Conference on Elementary Education 3, no. 1 (April 12, 2021): 359-63. http://proceedings2.upi.edu/index.php/icee/article/view/1486.

Weeks, Franscina Hester. "Behaviour Problems In The Classroom: A Model For Teachers To Assist Learners With Unmet Emotional Needs." Thesis, University of South Africa, 2000. https://uir.unisa.ac.za/handle/10500/17854.

Yulianingsih, Wiwin, and Rivo Nugroho. "Keterlibatan Orangtua Dalam Pendampingan Belajar Anak Selama Masa Pandemi Covid-19." Jurnal Obsesi: Jurnal Pendidikan Anak Usia Dini 5, no. 2 (2021): 1138-50. https://doi.org/10.31004/obsesi.v5i2.740. 